Conference being at the Konzerthaus, Lothringerstrasse 20, Vienna III. The theme of the Conference is "World Energy Resources in the Light of Recent Technical and Economic Developments", and the technical programme will consist of six divisions, at which the following topics will be discussed: the present status and development of power production and utilization in individual countries; the preparation and conversion of fuels ; utilization of primary sources of energy ; purification of waste water and exhaust gas in the production and use of energy; international co-operation in the production and use of energy. Short excursions will be available in Austria during the Conference, and afterwards a number of extensive tours of hydroelectric stations, power stations, etc., have been arranged in Austria, Yugoslavia, Italy and southern Germany. Further information is available from the various national committees, the British one being at 201-202 Grand Buildings, Trafalgar Square, London, W.C.2. Otherwise, all inquiries should be addressed to the Oesterreichisches Nationalkomitee der Weltkraftkonferenz, Vienna I., Schwarzenbergplatz 1.

\section{Chemical Society: Officers}

OfFICERS of the Chemical Society have been elected as follows: President, Prof. E. L. Hirst; Vice. Presidents, Sir Ian Heilbron, Sir Cyril Hinshelwood, Prof. C. K. Ingold, Dr. W. H. Mills, Sir Eric Rideal, Prof. W. Wardlaw, Prof, E. D. Hughes, Prof. E. R. H. Jones, Dr. R. P. Linstead, Prof. H. W. Melville, Prof. M. Stacey and Sir Alexander Todd; Honorary Treasurer, M. W. Perrin ; Honorary Secretaries, Dr. L. E. Sutton, Prof. F. Bergel and Dr. J. Chatt; New Members of Council, Prof. R. M. Barrer, Prof. A. G. Evans, Prof. L. Hunter, Dr. G. W. Kenner, Prof. B. Lythgoe, Dr. A. Maccoll and L. A. K. Staveley.

\section{University of Birmingham}

THE following have been appointed Research Fellows in the University of Birmingham : D. B. Holt (physical metallurgy) and Dr. G. Hübscher (pharma. cology). The University has received from Ciba, Ltd., of Basle, a Ciba research scholarship for three years of $£ 700$ year for the work and training of a graduate in the techniques of organic chemistry; in the first instance, the scholar will work on the synthesis of new halogen-containing organic compounds under the direction of Prof. M. Stacey. A grant of $£ 900$ has been made by the Electrical Research Association to the Department of Electrical Engineering of the University for the continuation of research work on electric discharges in liquids.

\section{Announcements}

DR. J. S. D. BACoN, senior lecturer in biochemistry, University of Sheffield, has been appointed head of the new Department of Biochemistry at the Macaulay Institute for Soil Research, Aberdeen, as from September 1 next.

The forty-first annual conference of the Textile Institute will be held in Blackpool during May 22-25, the subject for discussion being "New Yarns and Fabrics". Further information can be obtained from the Institute at 10 Blackfriars Street, Manchester 3.

AN international conference on "Nuclear Reactions", organized by the Nederlandse Natuurkundige Vereniging, will be held in Amsterdam during July 1-7. Among the topies discussed will be elastic and inelastic seattering, capture and photo reactions, stripping and pick-up reactions and fission. Further information can be obtained from the secretary of the conference committee, Dr. S. A. Wouthuysen, Zeeman Laboratorium, Pl. Muidergracht 4, Amsterdam $(C)$.

A SYMPosium on the methods, materials and processes involved in the uses of high temperatures in science and industry, organized jointly by the Stanford Research Institute and the University of California, Berkeley, will be beld in Berkeley during June 25-27. Further information can be obtained from Dr. Nevin K. Hiester, manager of the Chemical Engineering Section, Stanford Research Institute, Menlo Park, California.

Thw Second World Congress on Fertility and Sterility, sponsored by the International Fertility Association, will be held in Naples during May 18-26, the scientific sessions being held at the Palazzo Mostra di Oltremare and the inaugural session at the Castel Angioino. Simultaneous translations in English, French, Spanish and Italian, with the use of head-phones, will be available. In addition to the human aspects of the subject, there will be sessions on animal fertility and sterility. Further information can be obtained from Prof. G. Tesauro, Faculty of Medicine, University, Naples.

A syMPosIum on molecular structure and spectroscopy will be held in the Department of Physics and Astronomy of the Ohio State University during June 11-15. Both the interpretation of molecular spectroscopic results as well as methods for obtaining them will be discussed. The Joint Commission on Spectroscopy of the International Union of Pure and Applied Physics and the International Astronomical Union will meet concurrently with the symposium. Further information can be obtained from Prof. H. H. Nielsen, Department of Physics and Astronomy, Ohio State University, Columbus 10, Ohio.

THE annual meeting of the Société de Chimie Physique will be held in Paris during May 29June 1, when the subject, "Superficial Reactions of Gases on Metals", will be discussed. All the fundamental phenomena affecting the development and structure of thin films formed by gases on metal surfaces will be considered, with the exception of pure absorption and catalysis. Further information can be obtained from Prof. G. Emschwiller, École Supérieure de Physique et Chimie, 10 rue Vauquelin, Paris $5^{\mathrm{e}}$.

THE Fourth International Congress on Fruit Juices will be held in the Killesberg Park, Stuttgart, during May 28-June 2, the organizers being the Zentralverband der Sussmost- und Obstgetrankein-Industrie. The Congress is under the auspices of the International Federation of Fruit Juice Producers (Paris), and official representatives of the food and health services of twenty countries, as well as industrialists, exporters and importers, will be attending. The programme will include fifteen general reports and forty-four special reports, dealing with problems both from the point of view of medicine and hygiene and from the scientific, technical and practical angles; international questions referring to production, conditioning, sales and outlets will also be considered. Further information can be obtained from the office of the Congress at Bachstrasse 26, Bonn Rhein, Germany. 